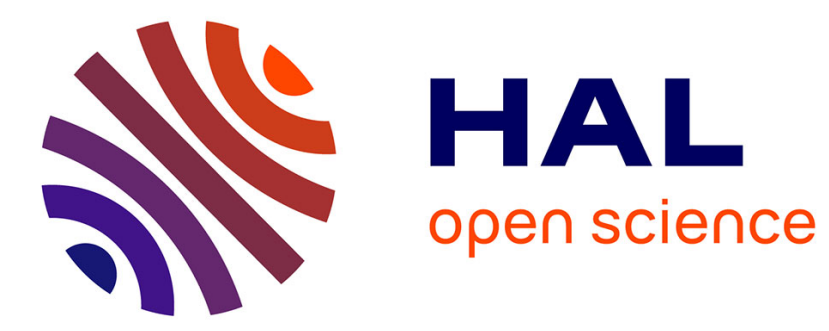

\title{
Post-malaria neurological syndrome: Imported case series and literature review to unscramble the auto-immune hypothesis
}

Antoine Poulet, Hanna Bou Ali, Hélène Savini, Elsa Kaphan, Philippe Parola

\section{- To cite this version:}

Antoine Poulet, Hanna Bou Ali, Hélène Savini, Elsa Kaphan, Philippe Parola. Post-malaria neurological syndrome: Imported case series and literature review to unscramble the auto-immune hypothesis. Travel Medicine and Infectious Disease, 2019, 29, pp.16-20. 10.1016/j.tmaid.2018.09.003 . hal-02507550

\section{HAL Id: hal-02507550 \\ https://hal-amu.archives-ouvertes.fr/hal-02507550}

Submitted on 25 Oct 2021

HAL is a multi-disciplinary open access archive for the deposit and dissemination of scientific research documents, whether they are published or not. The documents may come from teaching and research institutions in France or abroad, or from public or private research centers.
L'archive ouverte pluridisciplinaire HAL, est destinée au dépôt et à la diffusion de documents scientifiques de niveau recherche, publiés ou non, émanant des établissements d'enseignement et de recherche français ou étrangers, des laboratoires publics ou privés.

\section{(ㅇ)(1) $\$$}

Distributed under a Creative Commons Attribution - NonCommerciall 4.0 International 


\section{Post-malaria neurological syndrome: imported case series and}

\section{literature review to unscramble the auto-immune hypothesis}

Antoine POULET ${ }^{1}$, Hanna BOU $\mathrm{ALI}^{2}$, Helene SAVINI ${ }^{4}$, Elsa KAPHAN ${ }^{2}$, and Philippe PAROLA ${ }^{1^{*}}$

${ }^{1}$ Aix Marseille Univ, IRD, AP-HM, SSA, VITROME, IHU-Méditerranée Infection, Marseille, France.

${ }^{2}$ Pôle de Neurosciences Cliniques, CHU de la Timone, Assistance Publique - Hôpitaux de Marseille, Marseille, France.

${ }^{3}$ Service d'immunologie, CHU de la Timone, Assistance Publique - Hôpitaux de Marseille, Marseille, France.

${ }^{4}$ Service de pathologie infectieuse et tropicale, Hôpital d'instruction des armées Laveran, Marseille, France

*Corresponding author: Pr. Philippe Parola. Vecteurs - Infections Tropicales et Méditerranéennes (VITROME), IHU Méditerranée Infection. 19-21 Boulevard Jean Moulin 13005 Marseille, France Phone: + 33 (0) 4137324 01. Fax: + 33 (0) 4137324 02. E-mail address: philippe.parola@univamu.fr

\section{Conflicts of interest}

The authors declare that they have no competing interest. 


\section{ABSTRACT:}

Post-malaria neurological syndrome (PMNS) is a complication that occurs after recovery from a severe Plasmodium falciparum attack. Over the past two decades, the description of several imported cases has confirmed that this syndrome is a clearly distinct entity, different from other post malarial neurological disorders. However, the underlying mechanisms are not yet elucidated. Herein, we present five imported PMNS cases managed in Marseille, France. The detection of neuronal surface antibodies to an encephalitic syndrome of unknown origin allowed us to reveal positivity of anti Voltage-Gated-Potassium Chanel antibodies (anti VGKC) in one of them. Using treatment options from other autoimmune encephalitis has to be explored in patients with PMNS.

\section{Key-words:}

Malaria - Post-malaria neurological syndrome - Plasmodium falciparum - autoimmune encephalitis anti VGKC antibody 
Cerebral malaria is the most common neurological disorder that complicates severe Plasmodium falciparum infection. It has been linked with cerebral sequestration of parasitized red blood cells, cerebral inflammation and breakdown of blood-brain barrier[1]. In 1996, Nguyen et al. described a new entity they called post-malaria neurological syndrome (PMNS)[2]. It was reported as a neurological or psychiatric disorder occurring within two months of severe acute or cerebral malaria in a treated and cured patient (clearance of the parasites in the peripheral blood smears). This prospective study involved 22 patients in Vietnam suffering from clinical encephalopathy following confirmed infection with $P$. falciparum. The 22 patients recovered spontaneously without any specific treatment. Subsequently, 14 cases of PMNS following imported $P$. falciparum malaria were reported in the literature and reviewed by Markley et al in 2009[3]. This study has highlighted the characteristics common to both cases: PMNS has almost always been preceded by severe Plasmodium falciparum malaria; early clinical findings included altered consciousness, confusion, fever, generalized seizures, myoclonus, tremor, aphasia and/or psychosis. CSF study mostly exhibited lymphocytic pleocytosis with elevated protein; EEG revealed mild to severe encephalopathy and CT scan was still normal while MRI sometimes showed nonspecific signals. A rapid and effective response to corticosteroids in six of these cases led them to suggest an immune mechanism.

\section{Case reports}

Recently, we have reported the case of a PMNS in a 34-year-old white man with no significant medical history three weeks after having been cured from severe falciparum malaria following a trip in Benin and Mali without prophylaxis[4]. MRI was normal, EEG showed diffuse encephalopathy. CSF study, in addition to provide the PMNS expected elements (elevated protein and lymphocytic pleocytosis) showed intrathecal IgM synthesis with oligoclonal IgM bands. He was tested positive for antinuclear antibodies (titer 1/320), anti VGKC antibody (levels of $128 \mathrm{pmol} / \mathrm{l} ;$ normal range < 72pmol/I) suggesting autoimmune encephalitis as no other diagnosis was documented. He dramatically responded to high dose intravenous (IV) corticosteroid. Latter, while isolated attention 
disorder persisted, functional brain imaging with cerebral positron emission tomographic scan (PET$\mathrm{CT}$ ) disclosed abnormalities compatible with the diagnosis leading to repeat a 5-days high dose IV methylprednisolone. A new PET-CT several days after showed normal results while anti VGKC disappeared in plasma, as did serum antinuclear antibodies and oligoclonal CSF bands. In recent years, four other non-infectious post-malarial encephalitis syndromes have been treated in our units in Marseille. Including the case mentioned above, they were five males aged 16 to 59 with no personal or familial history of neurological or psychiatric disease. All were returning from SubSaharan Africa and presented signs of encephalitis with seizure, ataxia, myoclonus and pyramidal syndrome a few weeks after having been treated and cured from a severe $P$. falciparum infection of which two had cerebral malaria. The latency observed ranged from 10 to 103 days. All the CSF showed elevated protein and four of them had lymphocytic pleocytosis. Performed in 4 patients, EEG revealed to be abnormal for all of them while MRI was abnormal for two patients only. MRI changes were for patient 1, bilateral frontal T2 FLAIR weighted hypersignal and for patient 3, right frontal T2 weighted hypersignal. A complete resolution of symptoms was observed in all 5 patients. Normalization of the clinical status was obtained between 7 and 28 days. Two of them were treated with corticosteroid and showed significant improvement. Details are presented in Table 1.

\section{Discussion:}

Our five cases met the previously established criteria for PMNS, with the exception of one case with a latency of 103 days but no other diagnosis. All developed this encephalitic syndrome after recent and cured severe falciparum malaria. We observed a male predominance, as previously reported[3]. Besides, our patients shared common clinical characteristics including confusion, seizure, fever, ataxia and tremor, as reported in the few previously published cases. In our study, pyramidal syndrome was often present. The median onset was 4 days in the Vietnamese study, 15 days for those reviewed in 2009 and is 17 days for us. CSF studies showed lymphocytic pleocytosis in four out of five patients and always raised protein which is superior to the data collected by Markley and 
colleagues. The EEG is always abnormal when it is performed, perfectly congruent with the literature on the subject.

Interestingly, our last case[4] introduces various immune disorders that have never been tested or reported in PMNS before. This helped us clarifying the position of PMNS among other post infectious neurological syndromes. In front of this rapidly progressive encephalopathy of unclear etiology, founding low but significant positivity for antinuclear antibodies and lymphocytic CSF pleocytosis with intra-thecal synthesis of IgM led us to evoke an immune mediated process according to the current experience[5]. Antibody testing therefore performed showed positivity for antibodies against the voltage-gated potassium channel, associated to PET-CT abnormalities corroborating the hypothesis that PMNS precisely belongs to autoimmune encephalitis spectrum. Erasure of the anomalies three months after the acute phase is thus very consistent.

In order to assist physicians and practitioners and to facilitate identification of this infrequent clinical condition, Table 2 summarize the different neurological entities that could be encountered following a malaria treatment. In addition to PMNS, they are represented by delayed cerebellar ataxia (DCA) which is an acute inflammatory midline cerebellar ataxia[6], acute disseminated encephalomyelitis (ADEM) which is a central immune-mediated demyelinating disorder[7], acute inflammatory demyelinating polyradiculoneuropathy (AIDP) which is a monophasic peripheral demyelinating disease[8]. The nomenclature may be confusing since DCA and ADEM are autoimmune encephalitic syndromes but in this paper, the term autoimmune encephalitis refers specifically to the clinical finding as described in PMNS, associated with specific antibodies to the neuronal cell surface or synaptic proteins.

In ADEM, which broadly represent post infectious encephalopathies, many post infectious triggers have been described, mainly viral such as HSV[9], EBV[10], rubella[11], mumps[12] with some post vaccine forms (influenza, HBV, diphtheria-tetanus-polio)[13]. Bacterial infections of respiratory tract have been also implicated such as Mycoplasma pneumoniae[10], Chlamydia pneumoniae[14] and 
Legionella pneumophila[15]. Parasitic etiologies of post infectious ADEM such as Toxoplasma gondii

[16] are newly described in developing countries, however only about fourteen cases of ADEM following malaria cases are retrieved in the literature, Plasmodium falciparum and vivax[17] gathered. In comparison, PMNS appears to be a much more common cause of post-malarial encephalopathy.

Autoimmune encephalitis onset is also often preceded by infectious triggers. HSV-induced autoimmune encephalitis, mediated by antibodies against N-methyl-D-aspartate receptor (NMDAR) has already been described in patients presenting as HSV encephalitis relapse but with a negative polymerase chain reaction and a positivity of these antibodies[18].

Different primary mechanisms are proposed to explain how an infectious agent can induce autoimmunity. The oldest one is the molecular mimicry, supporting that there would be a crossreaction of antibodies against the pathogen to autoantigens of the CNS. The hypothesis of a strong or prolonged inflammatory response during and after severe malaria or in the case of a relapse has already been evoked as a risk factor for developing such a syndrome. Thus, the persistence of the $P$. falciparum-specific HRP2 antigen, usually more than 28 days after eradication, could carry on the immune response leading to the pathology[19]. Finally the last explanation could be that exposure to previously protected neuronal antigens during infection could generate secondary development of synaptic autoimmunity. The latter hypothesis, which is preferred for HSV-induced NMDAR encephalitis, seems difficult to apply in our cases, since only two of them experienced cerebral malaria.

In autoimmune encephalitis, anti-VGKC antibodies target extracellular receptors of neuronal cellsurface or synaptic proteins and can be found in paraneoplastic syndromes or in auto-immune non paraneoplastic encephalitis[5]. The neuronal dysfunction is caused by a direct interaction between the antibody and the autoantigen and is potentially reversible. They are classically opposed to autoimmune encephalitis with antibodies against intracellular proteins in which T-cell mediated 
cytotoxicity seems to be predominant, leading to an often irreversible neuronal dysfunction, with a lack of efficiency of the immunomodulating treatment[20].

Recently two cases of PMNS associated to neurexin-3alfa antibodies, another type of synaptic antibodies associated with autoimmune encephalitis, were reported. One is suspected and one is confirmed following malaria without severity criteria according to WHO but with a high parasitemia index (P. falciparum 8\%), treated with high dose IV methylprednisolone[21,22]. Just like anti-VGKC detection in our patient, this suggests that patient with autoimmune propensity could develop autoimmune encephalitis presenting as a post infectious encephalitis, particularly following malaria.

All the cases we had in Marseille met the criteria for autoimmune encephalitis even though the antibodies were not systematically dosed. The wide and expanding spectrum of neuronal cell surface antibodies $[23,24]$ raise the question of availability of the tests in healthcare settings. Retrospectively, knowing that this type of encephalitis is potentially responsive to specific immunotherapy should lead the clinician to provide himself the mean to appropriately screen patients with suspected autoimmune encephalitis. Therefore, we suggest that patients presenting with encephalitic syndrome after a severe and cured P. falciparum attack should first be tested for anti VGKC, anti LGI1 (leucine-rich glioma inactivated 1), anti CASPR2 (contactin-associated protein-like 2) and anti NMDAR which are the most frequently reported one. They should be tested both in serum and in CSF which provide a clean source of disease relevant antibodies. In negative case, other cell-surface/synaptic antigen (anti neurexin-3-alpha, anti GABAaR, anti GABAbR, anti DPPX, anti AMPAR)[24] should be tested. If these methodologies are not available in routine, aliquots should be sent to a center furnished with the adequate facilities for the future perspective of a better understanding of this disease. When discovered, those antibodies always requires for the clinician to rule out a neoplastic etiology.

However, it is important to specify that the antibody status is not mandatory to assume this diagnosis since they could be undetectable. Moreover, antibody testing could last several days, while 
a prompt and appropriate immunomodulating treatment has to be discussed[25] if autoimmune encephalitis is the most probable diagnosis. According to many humoral-mediated autoimmune diseases, the first-line treatment of autoimmune encephalitis with surface neuronal antibodies may consists of high-dose IV corticosteroids followed by progressive reduction with oral corticosteroids[26]. Therapeutic options for first-line treatment or in refractory cases include intravenous immunoglobulin[27] or plasmapheresis[28]. In the same way, some authors[29] have reported the efficiency of corticosteroid use in severe and non-resolving cases of PMNS. Given the dysimmunity markers found in PMNS suggesting analogy to autoimmune encephalitis with extracellular target, proposing the same type of immunotherapy seems to be relevant in the absence of robust studies to guide the clinician. As for the clinician, his main challenge is to be absolutely certain that all infectious causes have been excluded before giving such therapy.

\section{Conclusion:}

Since malaria is still an endemic disease in Sub Saharan Africa, South East Asia, Latin America and because people keep on traveling without taking malaria prophylaxis, new PMNS cases are expected following severe $P$. falciparum malaria. Warning the clinician and more particularly neurologists and specialists in infectious disease seems to be relevant, indeed the chance to be confronted to this difficult diagnosis and to follow a case of encephalitis after malaria treatment is not null.

The autoimmune mechanisms responsible for post-malaria neurological syndrome are still poorly understood, however, the constant progress in the discovery of new antibodies and their involvement in similar syndromes such as autoimmune encephalitis could be of great value to understanding such an interesting disease.

The therapeutic concerns about how and when PMNS should be treated with corticosteroid or other immunotherapy is still questioned and bringing out antibodies associated with autoimmune encephalitis could be helpful in the discussion. As a parallel, specific treatment should not only be reserved for severe cases with profound conscious impairment or with an epileptic condition that 
shows no sign of improvement. It should also be possible to give it to a patient complaining of even a mild cognitive neurological impairment, somatic, epileptic that is connected to the disease since those patients are usually young and active. However, all causes of infectious encephalitis must have been eliminated before treatment, especially a malaria relapse. 


\begin{tabular}{|c|c|c|c|c|c|}
\hline & Patient 1 & Patient 2 & Patient 3 & Patient 4 & Patient 5 [4] \\
\hline Travel country & Congo (2006) & Ivory Coast (2007) & Ivory Coast (2007) & $\begin{array}{l}\text { Benin, Togo, } \\
\text { Burkina Faso } \\
(2008)\end{array}$ & $\begin{array}{l}\text { Mali, Benin } \\
\text { (2015) }\end{array}$ \\
\hline Sex & Male & Male & Male & Male & Male \\
\hline Age (years) & 59 & 16 & 53 & 30 & 34 \\
\hline $\begin{array}{l}\text { Severe } P . \\
\text { falciparum }\end{array}$ & $\begin{array}{l}\text { Yes (cerebral } \\
\text { malaria) }\end{array}$ & $\begin{array}{l}\text { Yes (jaundice, } \\
\text { hemoglobinuria, } \\
\text { disseminated } \\
\text { intravascular } \\
\text { coagulation) }\end{array}$ & $\begin{array}{l}\text { Yes (hypotension, } \\
\text { jaundice, } \\
\text { hemoglobinuria) }\end{array}$ & Yes (jaundice) & $\begin{array}{l}\text { Yes (cerebral } \\
\text { malaria) }\end{array}$ \\
\hline Parasitemia & NA & NA & $26 \%$ & NA & $16 \%$ \\
\hline Treatment & Quinine & Mefloquine & Quinine & Quinine & $\begin{array}{l}\text { Artesunate- } \\
\text { artemether/lume } \\
\text { fantrine }\end{array}$ \\
\hline Latency (days) & 10 & 16 & 103 & 37 & 17 \\
\hline Symptoms & $\begin{array}{l}\text { Confusion, } \\
\text { dizziness, ataxia, } \\
\text { fine tremor, } \\
\text { aphasia, } \\
\text { pyramidal } \\
\text { syndrome }\end{array}$ & $\begin{array}{l}\text { Ataxia, fine } \\
\text { tremor, diplopia, } \\
\text { fever }\end{array}$ & $\begin{array}{l}\text { Confusion, ataxia, } \\
\text { seizure, athetosis, } \\
\text { fever }\end{array}$ & $\begin{array}{l}\text { Confusion, } \\
\text { impaired } \\
\text { consciousness, } \\
\text { ataxia, fine } \\
\text { tremor, seizure, } \\
\text { pyramidal } \\
\text { syndrome, fever }\end{array}$ & $\begin{array}{l}\text { Confusion, } \\
\text { dizziness, ataxia, } \\
\text { fine tremor, } \\
\text { fever, seizure, } \\
\text { pyramidal } \\
\text { syndrome }\end{array}$ \\
\hline CSF & $\begin{array}{l}3 \mathrm{WBC} / \mathrm{mm} 3, \\
\text { protein } 1.81 \mathrm{~g} / \mathrm{l}\end{array}$ & $\begin{array}{l}67 \text { WBC } / \mathrm{mm} 3 \text {, } \\
\text { lymphocytic, } \\
\text { protein } 1.03 \mathrm{~g} / \mathrm{l}\end{array}$ & $\begin{array}{l}38 \mathrm{WBC} / \mathrm{mm} 3 \text {, } \\
\text { lymphocytic, } \\
\text { protein } 1.7 \mathrm{~g} / \mathrm{I}\end{array}$ & $\begin{array}{l}32 \mathrm{WBC} / \mathrm{mm} 3 \text {, } \\
\text { lymphocytic, } \\
\text { protein } 0.62 \mathrm{~g} / \mathrm{l}\end{array}$ & $\begin{array}{l}180 \text { WBC } / \mathrm{mm} 3 \text {, } \\
\text { lymphocytic, } \\
\text { protein } 2.03 \mathrm{~g} / \mathrm{I} \\
\text { Intrathecal } \\
\text { synthesis }\end{array}$ \\
\hline Antibodies & NA & NA & NA & NA & $\begin{array}{l}\text { Antinuclear } \\
\text { antibodies 1:320 } \\
\text { AntiVGKC } \\
\text { 128pmol/I }\end{array}$ \\
\hline MRI & $\begin{array}{l}\text { Bilateral frontal } \\
\text { T2 FLAIR } \\
\text { weighted } \\
\text { hypersignal }\end{array}$ & Normal & $\begin{array}{l}\text { Right frontal T2 } \\
\text { weighted } \\
\text { hypersignal }\end{array}$ & Normal & Normal \\
\hline EEG & Abnormal & NS & Abnormal & Abnormal & Abnormal \\
\hline Corticotherapy & No & No & No & Yes & Yes \\
\hline Duration (days) & 14 & 7 & 7 & 10 & 29 \\
\hline
\end{tabular}

Table 1 Summary of the five PMNS cases diagnosed in Marseille

CSF : cerebrospinal fluid ; EEG : electroencephalogram; MRI : magnetic resonance imagining; NA : not available data; VGKC : voltage gated potassium channel; WBC : white blood cell count 


\begin{tabular}{|c|c|c|c|c|}
\hline & PMNS [3][4][21] & $\mathrm{DCA}[30][31]$ & ADEM[7][32][33] & AIDP[34] \\
\hline $\begin{array}{l}\text { Median latency } \\
\text { before onset } \\
\text { (days) }\end{array}$ & $\begin{array}{l}15 \text { (range } \\
2-57)\end{array}$ & $\begin{array}{l}13 \text { (range } 3-41 \text { ) } \\
\text { with persisting } \\
\text { parasitemia in } \\
\text { one third of } \\
\text { cases }\end{array}$ & 10 (range 2-60) & 12 (range 5-30) \\
\hline $\begin{array}{l}\text { Preceded by } \\
\text { severe malaria }\end{array}$ & $\begin{array}{l}\text { Yes }(97 \%) \text { and only with } P \text {. } \\
\text { falciparum }\end{array}$ & No & $\begin{array}{l}\text { Yes }(92 \%) \text { but } 6 \text { out } \\
\text { of } 14 \text { cases involved } \\
\text { P. vivax }\end{array}$ & No \\
\hline $\begin{array}{l}\text { Sex ratio } \\
\text { (male/female) }\end{array}$ & $2: 1$ & $8.25: 1$ & $0.44: 1$ & $1.7: 1$ \\
\hline Mean age (years) & 34 (range 6-61) & $\begin{array}{l}28 \text { (range } 16- \\
56)\end{array}$ & $\begin{array}{l}21 \text { (range } 1.5-54) \text {, } \\
\text { half of the case are } \\
\text { under } 15\end{array}$ & 34 (range 10-63) \\
\hline $\begin{array}{l}\text { Clinical } \\
\text { presentation }\end{array}$ & $\begin{array}{l}\text { Encephalitis with impaired } \\
\text { consciousness }(77 \%) \text {, confusion } \\
(66 \%) \text {, central fever }(50 \%), \\
\text { generalized seizure }(33 \%), \\
\text { myoclonus }(11 \%) \text {, aphasia } \\
(28 \%) \text {, tremor }(23 \%), \text { psychosis } \\
(17 \%)\end{array}$ & $\begin{array}{l}\text { Cerebellar ataxia } \\
\text { without } \\
\text { impaired } \\
\text { consciousness } \\
\text { or seizure } \\
(100 \%)\end{array}$ & $\begin{array}{l}\text { Typically multifocal } \\
\text { neurological signs } \\
\text { and encephalitis } \\
\text { with focal or } \\
\text { generalized seizures }\end{array}$ & $\begin{array}{l}\text { Progressive ascending } \\
\text { areflexic weakness } \\
(100 \%), \text { sensory } \\
\text { changes }(79 \%), \text { cranial } \\
\text { nervepalsies }(49 \%)\end{array}$ \\
\hline $\begin{array}{l}\text { Cerebrospinal } \\
\text { fluid }\end{array}$ & $\begin{array}{l}\text { Lymphocytic pleocytosis (50\%) } \\
\text { and elevated protein (69\%) }\end{array}$ & Always normal & $\begin{array}{l}\text { Typically } \\
\text { lymphocytic } \\
\text { pleocytosis and } \\
\text { elevated protein } \\
\text { without oligoclonal } \\
\text { band }\end{array}$ & $\begin{array}{l}\text { Always elevated protein } \\
\text { without pleocytosis }\end{array}$ \\
\hline Antibodies & $\begin{array}{l}\text { Anti VGKC } \\
\text { Anti neurexin-3alfa }\end{array}$ & NR & No & $\begin{array}{l}\text { NR } \\
\text { Anti ganglioside? }\end{array}$ \\
\hline $\begin{array}{l}\text { Magnetic } \\
\text { resonance } \\
\text { imaging }\end{array}$ & $\begin{array}{l}\text { Sometimes abnormal ( } 33 \%) \text {, } \\
\text { with increased T2 signal in } \\
\text { cerebral grey and white matter, } \\
\text { resolving in weeks }\end{array}$ & $\begin{array}{l}\text { NA, normal in a } \\
\text { case report }\end{array}$ & $\begin{array}{l}\text { Constantly } \\
\text { abnormal: cerebral, } \\
\text { white matter } \\
\text { lesions, cerebellar } \\
\text { and basal ganglia } \\
\text { involvement. } \\
\text { Lesions typically } \\
\text { persist several } \\
\text { month }\end{array}$ & Needless \\
\hline Electrophysiology & $\begin{array}{l}\text { Always abnormal EEG: diffuse } \\
\text { encephalopathy }\end{array}$ & $\begin{array}{l}\text { Always normal } \\
\text { EEG and ENMG }\end{array}$ & $\begin{array}{l}\text { NR but typically } \\
\text { abnormal EEG }\end{array}$ & $\begin{array}{l}\text { Always abnormal } \\
\text { ENMG : distal latency } \\
\text { prolongation, } \\
\text { conduction bloc, } \\
\text { reduction of conduction } \\
\text { velocity }\end{array}$ \\
\hline Specific treatment & $\begin{array}{l}\text { None }(83 \%) \text { Corticosteroids } \\
(17 \%)[3] \\
\text { IVIG? Plasmapheresis? }\end{array}$ & No & $\begin{array}{l}\text { Corticosteroids } \\
(92 \%)\end{array}$ & $\begin{array}{l}\text { None }(84 \%) \\
\text { IVIG }(4 \%), \\
\text { plasmapheresis (4\%) }\end{array}$ \\
\hline $\begin{array}{l}\text { Spontaneous } \\
\text { relapses }\end{array}$ & NR & No & $\begin{array}{l}\text { NR, but multiphasic } \\
\text { forms exists in } \\
\text { ADEM }\end{array}$ & No \\
\hline Sequelae / Death & No / No & No / No & Yes (21\%) / No & $\begin{array}{l}\text { Rare }(4 \%) \text { / Frequent } \\
(77 \%) \text { when respiratory } \\
\text { failure is present (39\%) }\end{array}$ \\
\hline
\end{tabular}

Table 2 Post infectious neurological complications likely to follow a recent cured malaria

ADEM : acute disseminated encephalomyelitis; AIDP : acute inflammatory demyelinating polyradiculopathy ; DCA : delayed cerebellar ataxia ; EEG : electroencephalography ; ENMG ; electroneuromyography ; IGIV : intravenous immunoglobulins ; $N A$ : not available NR : not reported; PMNS : post malaria neurological syndrome; VGKC : voltage gated potassium channel 


\section{References:}

[1] Idro R, Marsh K, John CC, Newton CRJ. Cerebral malaria: mechanisms of brain injury and strategies for improved neurocognitive outcome. Pediatr Res 2010;68:267-74. doi:10.1203/PDR.0b013e3181eee738.

[2] Nguyen TH, Day NP, Ly VC, Waller D, Mai NT, Bethell DB, et al. Post-malaria neurological syndrome. Lancet Lond Engl 1996;348:917-21.

[3] Markley JD, Edmond MB. Post-Malaria Neurological Syndrome: A Case Report and Review of the Literature. J Travel Med 2009;16:424-30. doi:10.1111/j.17088305.2009.00349.x.

[4] Sahuguet J, Poulet A, Bou Ali H, Parola P, Kaphan E. Postmalaria Neurologic SyndromeAutoimmune Encephalitis With Anti-Voltage-Gated Potassium-Channel Antibodies. Ann Intern Med 2017;167:70-1. doi:10.7326/L16-0651.

[5] Armangue T, Leypoldt F, Dalmau J. Auto-immune encephalitis as differential diagnosis of infectious encephalitis. Curr Opin Neurol 2014;27:361-8. doi:10.1097/WCO.0000000000000087.

[6] Senanayake N. Delayed cerebellar ataxia: a new complication of falciparum malaria? $\mathrm{Br}$ Med J Clin Res Ed 1987;294:1253-4.

[7] Carreira J, Casella MI, Ascenção BB, Luis NP, Gonçalves AC, Brito AP, et al. Acute disseminated encephalomyelitis, a rare post-malaria neurological complication: Case report and review of the literature. Travel Med Infect Dis 2018. doi:10.1016/j.tmaid.2018.03.005.

[8] Sokrab T-EO, Eltahir A, Idris MNA, Hamid M. Guillain-Barre syndrome following acute falciparum malaria. Neurology 2002;59:1281-3. doi:10.1212/WNL.59.8.1281. 
[9] Sarioglu B, Kose SS, Saritas S, Kose E, Kanik A, Helvaci M. Severe acute disseminated encephalomyelitis with clinical findings of transverse myelitis after herpes simplex virus infection. J Child Neurol 2014;29:1519-23. doi:10.1177/0883073813513334.

[10] Erol I, Ozkale Y, Alkan O, Alehan F. Acute disseminated encephalomyelitis in children and adolescents: a single center experience. Pediatr Neurol 2013;49:266-73. doi:10.1016/j.pediatrneurol.2013.03.021.

[11] Idrissova ZR, Boldyreva MN, Dekonenko EP, Malishev NA, Leontyeva IY, Martinenko IN, et al. Acute disseminated encephalomyelitis in children: clinical features and HLA-DR linkage. Eur J Neurol 2003;10:537-46.

[12] Kun-Long Hung, Hung-Tsai Liao, Min-Lan Tsai. Postinfectious Encephalomyelitis: Etiologic and Diagnostic Trends. J Child Neurol 2000;15:666-70. doi:10.1177/088307380001501005.

[13] Huynh W, Cordato DJ, Kehdi E, Masters LT, Dedousis C. Post-vaccination encephalomyelitis: literature review and illustrative case. J Clin Neurosci Off J Neurosurg Soc Australas 2008;15:1315-22. doi:10.1016/j.jocn.2008.05.002.

[14] Heick A, Skriver E. Chlamydia pneumoniae-associated ADEM. Eur J Neurol 2000;7:4358.

[15] Lau LML de, Siepman DAM, Remmers MJM, Terwindt GM, Hintzen RQ. Acute Disseminating Encephalomyelitis Following Legionnaires Disease. Arch Neurol 2010;67:623-6. doi:10.1001/archneurol.2010.75.

[16] Aksoy A, Tanir G, Ozkan M, Oguz M, Yıldız YT. Acute disseminated encephalomyelitis associated with acute Toxoplasma gondii Infection. Pediatr Neurol 2013;48:236-9. doi:10.1016/j.pediatrneurol.2012.11.004. 
[17] Mani S, Mondal SS, Guha G, Gangopadhyay S, Pani A, Das Baksi S, et al. Acute disseminated encephalomyelitis after mixed malaria infection (Plasmodium falciparum and Plasmodium vivax) with MRI closely simulating multiple sclerosis. The Neurologist 2011;17:276-8. doi:10.1097/NRL.0b013e3182173668.

[18] Morris NA, Kaplan TB, Linnoila J, Cho T. HSV encephalitis-induced anti-NMDAR encephalitis in a 67-year-old woman: report of a case and review of the literature. J Neurovirol 2016;22:33-7. doi:10.1007/s13365-015-0364-9.

[19] Houzé S, Boly MD, Le Bras J, Deloron P, Faucher J-F. PfHRP2 and PfLDH antigen detection for monitoring the efficacy of artemisinin-based combination therapy (ACT) in the treatment of uncomplicated falciparum malaria. Malar J 2009;8:211. doi:10.1186/1475-2875-8-211.

[20] Lancaster E, Dalmau J. Neuronal autoantigens-pathogenesis, associated disorders and antibody testing. Nat Rev Neurol 2012;8:380-90. doi:10.1038/nrneurol.2012.99.

[21] Costa A, Silva-Pinto A, Alves J, Neves N, Martínez-Hernández E, Abreu P, et al. Postmalaria neurologic syndrome associated with neurexin-3 $\alpha$ antibodies. Neurol Neuroimmunol Neuroinflammation 2017;4. doi:10.1212/NXI.0000000000000392.

[22] Gresa-Arribas N, Planagumà J, Petit-Pedrol M, Kawachi I, Katada S, Glaser CA, et al. Human neurexin-3 $\alpha$ antibodies associate with encephalitis and alter synapse development. Neurology 2016;86:2235-42. doi:10.1212/WNL.0000000000002775.

[23] Linnoila JJ, Rosenfeld MR, Dalmau J. Neuronal Surface Antibody-Mediated Autoimmune Encephalitis. Semin Neurol 2014;34:458-66. doi:10.1055/s-0034-1390394.

[24] Zuliani L, Zoccarato M, Gastaldi M, lorio R, Evoli A, Biagioli T, et al. Diagnostics of autoimmune encephalitis associated with antibodies against neuronal surface antigens. 
Neurol Sci Off J Ital Neurol Soc Ital Soc Clin Neurophysiol 2017;38:225-9.

doi:10.1007/s10072-017-3032-4.

[25] Graus F, Titulaer MJ, Balu R, Benseler S, Bien CG, Cellucci T, et al. A clinical approach to diagnosis of autoimmune encephalitis. Lancet Neurol 2016;15:391-404.

doi:10.1016/S1474-4422(15)00401-9.

[26] Dowling PC, Bosch VV, Cook SD. Possible beneficial effect of high-dose intravenous steroid therapy in acute demyelinating disease and transverse myelitis. Neurology 1980;30:33-6.

[27] Marchioni E, Marinou-Aktipi K, Uggetti C, Bottanelli M, Pichiecchio A, Soragna D, et al. Effectiveness of intravenous immunoglobulin treatment in adult patients with steroidresistant monophasic or recurrent acute disseminated encephalomyelitis. J Neurol 2002;249:100-4.

[28] Weinshenker BG, O’Brien PC, Petterson TM, Noseworthy JH, Lucchinetti CF, Dodick DW, et al. A randomized trial of plasma exchange in acute central nervous system inflammatory demyelinating disease. Ann Neurol 1999;46:878-86.

[29] Schnorf H, Diserens K, Schnyder H, Chofflon M, Loutan L, Chaves V, et al. Corticosteroidresponsive postmalaria encephalopathy characterized by motor aphasia, myoclonus, and postural tremor. Arch Neurol 1998;55:417-20.

[30] Senanayake N, de Silva HJ. Delayed cerebellar ataxia complicating falciparum malaria: a clinical study of 74 patients. J Neurol 1994;241:456-9.

[31] Sakaria AK, Mahajan SK, Desai RR, Shah KB. Delayed cerebellar ataxia: A rare self limiting complication of plasmodium falciparum malaria. Adv Biomed Res 2013;2:27. doi:10.4103/2277-9175.107997. 
[32] Pohl D, Alper G, Van Haren K, Kornberg AJ, Lucchinetti CF, Tenembaum S, et al. Acute disseminated encephalomyelitis: Updates on an inflammatory CNS syndrome.

Neurology 2016;87:S38-45. doi:10.1212/WNL.0000000000002825.

[33] Höllinger P, Sturzenegger M, Mathis J, Schroth G, Hess CW. Acute disseminated encephalomyelitis in adults: a reappraisal of clinical, CSF, EEG, and MRI findings. J Neurol 2002;249:320-9. doi:10.1007/s004150200012.

[34] Berkowitz AL, Thakur KT. Acute inflammatory demyelinating polyradiculoneuropathy following malaria. J Clin Neurosci 2014;21:704-6. doi:10.1016/j.jocn.2013.07.031. 